\title{
BMJ Open Prayer or spiritual healing as adjuncts to conventional care: a cross sectional analysis of prevalence and characteristics of use among women
}

\author{
Angela Rao, ${ }^{1}$ David Sibbritt, ${ }^{2}$ Jane L Phillips, ${ }^{3}$ Louise D Hickman ${ }^{1}$
}

To cite: Rao A, Sibbritt D, Phillips JL, et al. Prayer or spiritual healing as adjuncts to conventional care: a cross sectional analysis of prevalence and characteristics of use among women. BMJ Open 2015;5:e007345. doi:10.1136/bmjopen-2014007345

- Prepublication history for this paper is available online. To view these files please visit the journal online (http://dx.doi.org/10.1136/ bmjopen-2014-007345).

Received 2 December 2014 Revised 5 March 2015 Accepted 20 March 2015

CrossMark

\footnotetext{
${ }^{1}$ Faculty of Health, University of Technology Sydney, New South Wales, Australia

${ }^{2}$ Australian Research Centre in Complementary and Integrative Medicine, Faculty of Health, University of Technology Sydney

${ }^{3}$ Centre for Cardiovascular and Chronic Care, Faculty of Health, University of Technology Sydney
}

\section{Correspondence to} Angela Rao; angela.rao@student. uts.edu.au

\section{ABSTRACT}

Objectives: To determine the prevalence and characteristics of users of prayer or spiritual healing among women.

Design and setting: This cross sectional study was conducted as a part of the Australian Longitudinal Study on Women's Health (ALSWH), a 20-year study that examines various factors affecting women's health and well-being.

Participants: The sample used in the current study were women from the 1946-1951 cohort $(n=9965)$ (59-64 years) who were surveyed in 2010.

Outcome measures: Use of prayer or spiritual healing; demographic factors and measures of health status. $\chi^{2}$ Tests, analyses of variance (to determine associations) and a stepwise backward logistic regression model (for the most significant predictors) using a likelihood ratio test were used to determine the outcome measures.

Results: It is estimated that $26 \%$ of Australian women from the 1946-1951 cohort (aged 59-64 years) use prayer or spiritual healing on a regular basis. Women were significantly more likely to use prayer or spiritual healing if they were non-smokers, non-drinkers or lowrisk drinkers, had symptoms of severe tiredness (OR 1.25; 95\% Cl 1.12 to 1.40), depression, (OR 1.30; $95 \% \mathrm{Cl} 1.11$ to 1.53 ), anxiety (OR $1.33 ; 95 \% \mathrm{Cl} 1.15$ to 1.53 ), diagnosed cancer (OR $1.84 ; 95 \% \mathrm{Cl} 1.28$ to 2.65 ) or other major illnesses (OR $1.43 ; 95 \% \mathrm{Cl} 1.18$ to 1.75 ) and used other complementary therapies.

Conclusions: A significant proportion of adult women are using prayer or spiritual healing. Given that prayer or spiritual healing was significantly associated with health symptoms, chronic illnesses and positive health seeking behaviours, respect for prayer or spiritual healing practices is required within health care settings. Future research is recommended around specific populations using prayer or spiritual healing, reasons for their use and potential benefits on health related outcomes and general well-being.

\section{INTRODUCTION}

Prayer and spiritual healing are a significant part of the medical system of many non-

\section{Strengths and limitations of this study}

- A stepwise backward logistic regression model and a likelihood ratio test allowed demonstration of the most significant predictors of use of prayer or spiritual healing.

- Use of prayer or spiritual healing was higher in women with health symptoms, diagnosed chronic illnesses, positive health-seeking behaviours and users of other complementary therapies.

- A nationally representative sample was utilised, however, response bias is likely given underrepresentation of some migrant groups and overrepresentation of tertiary qualified women.

- The dataset did not include men, thereby limiting generalisability of the results to the wider population.

western countries. ${ }^{1-3}$ Spiritual healing is used widely in the UK, with nine separate healing organisations registering approximately 13000 healers, and in the USA using the modality of Therapeutic Touch, ${ }^{4}$ while the Australian setting comprises of multiple smaller organisations. ${ }^{56}$

Dossey $^{7}$ defined prayer as the conscious willing intent of one or more persons for the well-being of self (personal prayer) or others (intercessory prayer) that may be initiated as a conscious activity or from the unconscious mind. Benor ${ }^{8}$ in page 4 of 'Spiritual Healing', defined spiritual healing concisely as the "systematic, purposeful intervention by one or more persons aimed to help another person by focused intention (including hand contact or hand passes) to improve their condition."

Use of prayer or spiritual healing in the US setting indicates that $64.1 \%$ of community dwelling older adults report using prayer or spiritual healing on a daily basis. ${ }^{9}$ Nationally representative samples in the USA are ambiguous regarding use of prayer or spiritual healing. Barnes et $a l^{10}$ indicated that $43 \%$ of adults over 18 years of age report 
using prayer for health, and $24.4 \%$ reported using prayer for the health of others; while an earlier survey found that $7 \%$ of the population use either prayer or spiritual healing. ${ }^{11}$ In the Australian setting, use of prayer or spiritual healing was reported to be used among $24.4 \%$ of a nationally representative sample of women using self-prescribed complementary and alternative medicine (CAM). ${ }^{12}$

Two previous systematic reviews determining the efficacy of prayer or spiritual healing therapies were inconclusive or equivocal given the early stages of research in this area. ${ }^{13}{ }^{14}$ While the Cochrane review concluded that no changes to current intercessory prayer practices were required given the low risk of the intervention, another review recommended that spiritual competence and relevant training were required before allied health staff prayed with clients, however, silent prayer may be beneficial if performed without obtaining the patient's consent. $^{13-15}$

The largest systematic review by Benor, ${ }^{8}$ involving cells, plants, animal and human populations, found spiritual healing to be effective as an adjunctive treatment to conventional care. Three further systematic reviews were inconclusive and determined that further methodologically strong studies were needed that include the assessment of potentially confounding factors such as expectation and belief. ${ }^{16-18}$

In the Australian setting, characteristics of users of prayer or spiritual healing have yet to be explored. Previous research has indicated that, in the USA, prayer for health reasons or prayer for self was more likely to be used among adults of low socioeconomic status, women and African-Americans. ${ }^{10} 19{ }^{20}$ Use of prayer has been positively correlated with five or more chronic conditions, poorer self-rated health, age and residence within the south-western areas of the USA. ${ }^{20}$ Adults under 65 years of age with public health insurance and living in urban areas, who were hospitalised in the past 12 months, and former smokers, were also more likely to use prayer for health reasons. ${ }^{10}$ This differs from the general characteristics of CAM users who are more likely to have above-average incomes, be well educated and employed, and have private health insurance; however, CAM users generally are also more likely to be female. ${ }^{21}$ Factors related to use of spiritual healing have yet to be explored worldwide.

The aims of the study are to: estimate the prevalence of use of prayer or spiritual healing in Australian women; and identify the demographic, health status and health service utilisation factors associated with the use of prayer or spiritual healing among Australian women.

\section{METHODS}

Study participants

The Australian Longitudinal Study on Women Health (ALSWH) is a population-based study conducted over a 20-year period, and is designed to explore the physical health, emotional well-being, biological, psychosocial, lifestyle and health service utilisation factors affecting the health of women. ${ }^{22}$ Eligibility criteria included women who were registered on the Australian Medicare database, assumed to be the most accurate representation of Australian women given registration of close to all women on a government health agency database including citizens and permanent residents, such as migrant and refugee women. ${ }^{22}$ Random sampling was used to recruit women into three 'young' (1973-1978), 'mid' (1946-1951) and 'older' (1921-1926) cohorts, which were nationally representative samples for the respective age groups, however, there was some response bias with over-representation of women with a tertiary qualification and under-representation of women from some ethnic minority population groups. ${ }^{22}$

The baseline survey in 1996 included 14099 respondents in the mid cohort, however, only the most recent survey (conducted in 2010) was used in this analysis. ${ }^{23}$

\section{Data collected}

Prevalence (primary outcome measure)

Women were asked about their frequency of use of prayer or spiritual healing within the previous 12 months.

\section{Demographic characteristics}

Urban, rural or remote comparisons for areas of residence were made by means of current geographical postcode. Other demographic data collected included age (in years), level of education, marital status, ability to manage on available income, smoking status, alcohol use and health insurance for hospital cover or ancillary services.

\section{Health status}

Women were asked questions about the frequency of experiencing health symptoms in the past 12 months or diagnosed conditions within the past 3 years. Symptoms included difficulty breathing, chest pain, stiff or painful joints, back pain, depression, anxiety, intense anxiety such as panic attacks, constipation, difficulty sleeping, palpitations, dizziness, loss of balance or difficulty concentrating. Diagnosed conditions referred to diabetes, impaired glucose tolerance, rheumatoid arthritis, osteoarthritis, other arthritis, hypertension, heart disease, asthma, bronchitis or emphysema, osteoporosis, breast cancer, skin cancer, other cancer or other major illnesses.

\section{Statistical analysis}

The STATA program was used to complete all analyses. To determine associations between categorical, demographic and health status factors and use of prayer or spiritual healing, $\chi^{2}$ tests were used. A one way analysis of variance (ANOVA) was employed to determine differences in mean scores between continuous demographic and health status factors and the use of prayer or spiritual healing. To determine the most parsimonious model, demographic and health status factors that were 
significant at the $\mathrm{p}<0.25$ level were entered into a logistic regression model followed by the use of a stepwise backward elimination process using a likelihood ratio test. ${ }^{23}{ }^{24}$ Statistical significance was set at $\mathrm{p}<0.005$ due to the large sample size.

A signed consent form attached to the returned questionnaire and invitation to participate was used as informed consent. $^{25}$

\section{RESULTS}

A total of 12064 participants were eligible for the 2010 survey. There was a total of 1651 ineligible participants due to death $(n=472)$, frailty $(n=67)$ or withdrawal from the study $(n=1112) .{ }^{26}$ The response rate was $83 \%$ $(n=10011)$ from the $1946-1951$ cohort in $2010 .{ }^{26}$ The majority of non-respondents were contactable, but did not complete the survey $(\mathrm{n}=1148)$; or were not contactable $(n=905)$ and excluded from the analysis $(\mathrm{n}=2053) .{ }^{26}$
Participants from the 1946-1951 cohort were of predominately rural or remote residence $(61.2 \%)$, married or in a de facto relationship (76.9\%), had a school level of education $(58.5 \%)$ and were able to manage well on available income $(62.9 \%)$.

For questions relating to individual health symptoms, missing data varied between $0.8 \%$ to $3.4 \% .{ }^{26}$ Data were missing for $0.9 \%$ of participants for questions relating to diagnosed conditions within the past 3 years, while $0.3-$ $1.3 \%$ of answers were missing for questions related to the use of complementary therapies. ${ }^{26}$

A total of $9965(99.5 \%)$ women answered the question regarding the use of prayer or spiritual healing. Among these women, prayer or spiritual healing was used often by $14 \%(\mathrm{n}=1385)$, used sometimes by $12 \%(\mathrm{n}=1211)$, used rarely by $6 \%(\mathrm{n}=599)$ and never used by $68 \%(\mathrm{n}=6770)$.

Table 1 shows the symptoms of chronic illness associated with the use of prayer or spiritual healing. Compared to women who never or rarely experienced these symptoms, women who used prayer or spiritual healing were

Table 1 The association between symptoms of chronic illness and use of prayer or spiritual healing by women aged 59-64 years in 2010

\begin{tabular}{|c|c|c|c|c|c|}
\hline \multirow[b]{2}{*}{ Health symptoms } & \multicolumn{5}{|c|}{ Use of prayer or spiritual healing } \\
\hline & $\begin{array}{l}\text { Never } \\
(n=6770),(\%)\end{array}$ & $\begin{array}{l}\text { Rarely } \\
(\mathrm{n}=599),(\%)\end{array}$ & $\begin{array}{l}\text { Sometimes } \\
(n=1211),(\%)\end{array}$ & $\begin{array}{l}\text { Often } \\
(n=1385),(\%)\end{array}$ & p Value \\
\hline \multicolumn{6}{|l|}{ Breathing difficulty } \\
\hline Never/rarely & 85 & 84 & 83 & 83 & \multirow[t]{2}{*}{0.163} \\
\hline Sometimes/often & 15 & 16 & 17 & 17 & \\
\hline \multicolumn{6}{|l|}{ Chest pain } \\
\hline Never/rarely & 92 & 90 & 90 & 89 & \multirow[t]{2}{*}{0.002} \\
\hline Sometimes/often & 8 & 10 & 10 & 11 & \\
\hline \multicolumn{6}{|l|}{ Stiff or painful joints } \\
\hline Never/rarely & 36 & 31 & 35 & 35 & \multirow[t]{2}{*}{0.045} \\
\hline Sometimes/often & 64 & 69 & 65 & 65 & \\
\hline \multicolumn{6}{|l|}{ Back pain } \\
\hline Never/rarely & 46 & 42 & 42 & 43 & \multirow[t]{2}{*}{0.005} \\
\hline Sometimes/often & 54 & 58 & 58 & 57 & \\
\hline \multicolumn{6}{|l|}{ Depression } \\
\hline Never/rarely & 82 & 76 & 75 & 75 & \multirow[t]{2}{*}{$<0.001$} \\
\hline Sometimes/often & 18 & 24 & 25 & 25 & \\
\hline \multicolumn{6}{|l|}{ Anxiety } \\
\hline Never/rarely & 78 & 70 & 69 & 68 & \multirow[t]{2}{*}{$<0.001$} \\
\hline Sometimes/often & 22 & 30 & 31 & 32 & \\
\hline \multicolumn{6}{|l|}{ Intense anxiety } \\
\hline Never/rarely & 93 & 92 & 92 & 92 & \multirow[t]{2}{*}{0.300} \\
\hline Sometimes/often & 7 & 8 & 8 & 8 & \\
\hline \multicolumn{6}{|l|}{ Palpitations } \\
\hline Never/rarely & 83 & 78 & 79 & 79 & \multirow[t]{2}{*}{$<0.001$} \\
\hline Sometimes/often & 17 & 22 & 21 & 21 & \\
\hline \multicolumn{6}{|c|}{ Dizziness/loss of balance } \\
\hline Never/rarely & 83 & 82 & 81 & 80 & \multirow[t]{2}{*}{0.035} \\
\hline Sometimes/often & 17 & 18 & 19 & 20 & \\
\hline \multicolumn{6}{|c|}{ Difficulty concentrating } \\
\hline Never/rarely & 76 & 73 & 70 & 69 & \multirow[t]{2}{*}{$<0.001$} \\
\hline Sometimes/often & 24 & 27 & 30 & 31 & \\
\hline \multicolumn{6}{|l|}{ Difficulty sleeping } \\
\hline No & 64 & 60 & 63 & 64 & \multirow[t]{2}{*}{0.206} \\
\hline Yes & 36 & 40 & 37 & 36 & \\
\hline
\end{tabular}


significantly more likely to have sometimes or often experienced: chest pain $(\mathrm{p}=0.002)$; back pain $(\mathrm{p}=0.005)$; poor memory $(p<0.001)$; depression $(p<0.001)$; anxiety $(\mathrm{p}<0.001)$; palpitations $(\mathrm{p}<0.001)$; and/or difficulty concentrating $(p<0.001)$.

The association between diagnosed conditions and the use of prayer or spiritual healing is presented in table 2. In contrast to women who had not been diagnosed with any of these conditions, women who used prayer or spiritual healing were significantly more likely to have been diagnosed with: impaired glucose tolerance ( $\mathrm{p}=0.005)$; asthma $(\mathrm{p}<0.0001)$; other cancer diagnosis (other than breast or skin cancer) $(\mathrm{p}<0.001)$; and/or another major illness $(\mathrm{p}<0.001)$.

Table 3 demonstrates the association between the use of complementary therapies and use of prayer or spiritual healing in women. Women who used vitamins or minerals sometimes or often were significantly more likely to use prayer or spiritual healing compared to women who never or rarely used vitamins or minerals $(\mathrm{p}<0.001)$. Compared to women who never or rarely used yoga or meditation, women who used yoga or meditation sometimes or often were significantly more likely to use prayer or spiritual healing $(\mathrm{p}<0.001)$. Use

Table 2 The association between diagnosed chronic illnesses and use of prayer or spiritual healing by women aged $59-64$ years in 2010

\begin{tabular}{|c|c|c|c|c|c|}
\hline \multirow[b]{2}{*}{ Condition } & \multicolumn{5}{|c|}{ Use of prayer or spiritual healing } \\
\hline & Never (n=6770), (\%) & Rarely (n=599), (\%) & Sometimes ( $n=1211),(\%)$ & Often ( $n=1385),(\%)$ & p Value \\
\hline \multicolumn{6}{|l|}{ Diabetes } \\
\hline No & 92 & 95 & 92 & 92 & 0.074 \\
\hline Yes & 8 & 5 & 8 & 8 & \\
\hline \multicolumn{6}{|c|}{ Impaired glucose tolerance } \\
\hline No & 97 & 98 & 98 & 96 & 0.005 \\
\hline Yes & 3 & 2 & 2 & 4 & \\
\hline \multicolumn{6}{|c|}{ Osteoarthritis } \\
\hline No & 82 & 80 & 81 & 79 & 0.113 \\
\hline Yes & 18 & 20 & 19 & 21 & \\
\hline \multicolumn{6}{|c|}{ Rheumatoid arthritis } \\
\hline No & 95 & 95 & 96 & 95 & 0.710 \\
\hline Yes & 5 & 5 & 4 & 5 & \\
\hline \multicolumn{6}{|c|}{ Other arthritis } \\
\hline No & 87 & 88 & 86 & 86 & 0.552 \\
\hline Yes & 13 & 12 & 14 & 14 & \\
\hline \multicolumn{6}{|c|}{ Heart disease } \\
\hline No & 96 & 96 & 95 & 95 & 0.219 \\
\hline Yes & 4 & 4 & 5 & 5 & \\
\hline \multicolumn{6}{|c|}{ Hypertension } \\
\hline No & 70 & 68 & 69 & 69 & 0.779 \\
\hline Yes & 30 & 32 & 31 & 31 & \\
\hline \multicolumn{6}{|l|}{ Asthma } \\
\hline No & 90 & 89 & 85 & 88 & $<0.001$ \\
\hline Yes & 10 & 11 & 15 & 12 & \\
\hline \multicolumn{6}{|c|}{ Bronchitis/emphysema } \\
\hline No & 94 & 93 & 93 & 92 & 0.051 \\
\hline Yes & 6 & 7 & 7 & 8 & \\
\hline \multicolumn{6}{|c|}{ Osteoporosis } \\
\hline No & 93 & 93 & 93 & 92 & 0.217 \\
\hline Yes & 7 & 7 & 7 & 8 & \\
\hline \multicolumn{6}{|c|}{ Breast cancer } \\
\hline No & 98 & 98 & 97 & 98 & 0.647 \\
\hline Yes & 2 & 2 & 3 & 2 & \\
\hline \multicolumn{6}{|l|}{ Skin cancer } \\
\hline No & 86 & 85 & 86 & 86 & 0.853 \\
\hline Yes & 14 & 15 & 14 & 14 & \\
\hline \multicolumn{6}{|c|}{ Other cancer } \\
\hline No & 99 & 99 & 98 & 97 & $<0.001$ \\
\hline Yes & 1 & 1 & 2 & 3 & \\
\hline \multicolumn{6}{|c|}{ Other major illnesses } \\
\hline No & 95 & 96 & 92 & 91 & $<0.001$ \\
\hline Yes & 5 & 4 & 8 & 9 & \\
\hline
\end{tabular}


Table 3 The association between use of complementary therapies and use of prayer or spiritual healing by women aged 59-64 years in 2010

\begin{tabular}{|c|c|c|c|c|c|}
\hline \multirow[b]{2}{*}{$\begin{array}{l}\text { Use of complementary } \\
\text { therapies }\end{array}$} & \multicolumn{5}{|c|}{ Use of prayer or spiritual healing } \\
\hline & $\begin{array}{l}\text { Never } \\
(n=6770),(\%)\end{array}$ & $\begin{array}{l}\text { Rarely } \\
(\mathrm{n}=599),(\%)\end{array}$ & $\begin{array}{l}\text { Sometimes } \\
(n=1211),(\%)\end{array}$ & $\begin{array}{l}\text { Often } \\
(n=1385),(\%)\end{array}$ & p Value \\
\hline \multicolumn{6}{|l|}{ Vitamins/minerals } \\
\hline Never/rarely & 36 & 24 & 22 & 19 & $<0.001$ \\
\hline Sometimes/often & 64 & 76 & 78 & 81 & \\
\hline \multicolumn{6}{|l|}{ Yoga/meditation } \\
\hline Never/rarely & 88 & 75 & 69 & 68 & $<0.001$ \\
\hline Sometimes/often & 12 & 25 & 31 & 32 & \\
\hline \multicolumn{6}{|l|}{ Herbal medicine } \\
\hline Never/rarely & 78 & 63 & 65 & 60 & $<0.001$ \\
\hline Sometimes/often & 22 & 37 & 35 & 40 & \\
\hline \multicolumn{6}{|l|}{ Aromatherapy } \\
\hline Never/rarely & 90 & 77 & 74 & 75 & $<0.001$ \\
\hline Sometimes/often & 10 & 23 & 26 & 25 & \\
\hline \multicolumn{6}{|l|}{ Chinese medicine } \\
\hline Never/rarely & 98 & 92 & 94 & 94 & $<0.001$ \\
\hline Sometimes/often & 2 & 8 & 6 & 6 & \\
\hline \multicolumn{6}{|l|}{ Other alternative therapies } \\
\hline Never/rarely & 96 & 89 & 82 & 80 & $<0.001$ \\
\hline Sometimes/often & 4 & 11 & 18 & 20 & \\
\hline
\end{tabular}

of prayer or spiritual healing was significantly more likely in women who sometimes or often used herbal medicines compared to women who never or rarely used herbal medicines $(\mathrm{p}<0.001)$. Women who used aromatherapy oils sometimes or often were significantly more likely to use prayer or spiritual healing compared to women who never or rarely used aromatherapy oils $(\mathrm{p}<0.001)$. Women who used Chinese medicines sometimes or often were significantly more likely to use prayer or spiritual healing compared to women who never or rarely used Chinese medicines $(p<0.001)$. In comparison with women who never or rarely used other alternative medicines, women who used other alternative medicines sometimes or often were significantly more likely to use prayer or spiritual healing $(\mathrm{p}<0.001)$.

The statistically significant predictors of the use of prayer or spiritual healing are shown in table 4. Women with a trade qualification, certificate or diploma were 1.28 (95\% CI 1.13 to 1.46 ) more likely to use prayer or spiritual healing than women with no formal education, or women who completed school only. Compared to women who had never smoked, ex-smokers were 0.78 (95\% CI 0.69 to 0.87 ) times less likely to use prayer or spiritual healing while current smokers were $0.64(95 \%$ CI 0.52 to 0.78 ) times less likely to use prayer or spiritual healing than women who had never smoked.

Women classified as risky drinkers or high-risk drinkers were 0.63 (95\% CI 0.50 to 0.79 ) times less likely to use prayer or spiritual healing than women classified as non-drinkers or low-risk drinkers. Women who reported suffering from severe tiredness sometimes or often were 1.25 (95\% CI 1.12 to 1.40 ) times more likely to use prayer or spiritual healing than women who reported never or rarely suffering from severe tiredness. Compared to women who never or rarely suffered from self-reported depression, women who suffered from selfreported depression sometimes or often were 1.30 (95\% CI 1.11 to 1.53 ) times more likely to use prayer or spiritual healing. Compared to women who never or rarely reported anxiety, women who reported anxiety sometimes or often were 1.33 (95\% CI 1.15 to 1.53 ) times more likely to use prayer or spiritual healing.

Women who had a diagnosed cancer other than breast, cervical or skin cancer were 1.84 (95\% CI 1.28 to 2.65) times more likely to use prayer or spiritual healing than women who did not have a cancer diagnosis other than breast, cervical or skin cancer. Women who had been diagnosed with another major illness or disability were 1.43 times (95\% CI 1.18 to 1.75 ) more likely to use prayer or spiritual healing than women who did not have a diagnosed major illness or disability.

Use of vitamins or minerals among women sometimes or often was correlated with a 1.61 (95\% CI 1.42 to 1.82) times greater likelihood of using prayer or spiritual healing than use of vitamins or minerals never or rarely. Use of yoga or meditation sometimes or often was associated with a 2.00 (95\% CI 1.75 to 2.28) times greater likelihood of using prayer or spiritual healing among women than use of yoga or mediation never or rarely. Women who used herbal medicines sometimes or often were 1.19 (95\% CI 1.05 to 1.34 ) times more likely to use prayer or spiritual healing than women who used herbal medicines never or rarely. Compared to women who used aromatherapy oils never or rarely, women who used aromatherapy oils sometimes or often were 1.59 (95\% CI 1.39 to 1.83 ) times more likely to use prayer or 
Table 4 Multiple logistic regression model for predicting use of prayer or spiritual healing compared for women aged 59-64 years in 2010

\begin{tabular}{|c|c|c|c|}
\hline Factor & OR & $95 \% \mathrm{Cl}$ & $\mathrm{p}$ Value \\
\hline \multicolumn{4}{|l|}{ Education } \\
\hline None, year 10, year 12 & 1.00 & - & \\
\hline Trade/certificate/diploma & 1.28 & 1.13 to 1.46 & 0.001 \\
\hline University/higher degree & 0.99 & 0.86 to 1.13 & 0.835 \\
\hline \multicolumn{4}{|l|}{ Smoking status } \\
\hline Non-smoker & 1.00 & - & \\
\hline Ex-smoker & 0.78 & 0.69 to 0.87 & 0.001 \\
\hline Current smoker & 0.64 & 0.52 to 0.78 & 0.001 \\
\hline \multicolumn{4}{|l|}{ Alcohol use } \\
\hline Non-drinker/low risk & 1.00 & - & \\
\hline Risky/high risk & 0.63 & 0.50 to 0.79 & 0.001 \\
\hline \multicolumn{4}{|l|}{ Severe tiredness } \\
\hline Never/rarely & 1.00 & - & \\
\hline Sometimes/often & 1.25 & 1.12 to 1.40 & 0.001 \\
\hline \multicolumn{4}{|l|}{ Depression } \\
\hline Never/rarely & 1.00 & - & \\
\hline Sometimes/often & 1.30 & 1.11 to 1.53 & 0.001 \\
\hline \multicolumn{4}{|l|}{ Anxiety } \\
\hline Never/rarely & 1.00 & - & \\
\hline Sometimes/often & 1.33 & 1.15 to 1.53 & 0.001 \\
\hline \multicolumn{4}{|l|}{ Other cancer } \\
\hline No & 1.00 & - & \\
\hline Yes & 1.84 & 1.28 to 2.65 & 0.001 \\
\hline \multicolumn{4}{|l|}{ Other major illness or disability } \\
\hline No & 1.00 & - & \\
\hline Yes & 1.43 & 1.18 to 1.75 & 0.001 \\
\hline \multicolumn{4}{|l|}{ Vitamins/minerals } \\
\hline Never/rarely & 1.00 & - & \\
\hline Sometimes/often & 1.61 & 1.42 to 1.82 & 0.001 \\
\hline \multicolumn{4}{|l|}{ Yoga/meditation } \\
\hline Never/rarely & 1.00 & - & \\
\hline Sometimes/often & 2.00 & 1.75 to 2.28 & 0.001 \\
\hline \multicolumn{4}{|l|}{ Herbal medicines } \\
\hline Never/rarely & 1.00 & - & \\
\hline Sometimes/often & 1.19 & 1.05 to 1.34 & 0.006 \\
\hline \multicolumn{4}{|l|}{ Aromatherapy oils } \\
\hline Never/rarely & 1.00 & - & \\
\hline Sometimes/often & 1.59 & 1.39 to 1.83 & 0.000 \\
\hline \multicolumn{4}{|l|}{ Other alternative therapy } \\
\hline Never/rarely & 1.00 & - & \\
\hline Sometimes/often & 2.47 & 2.07 to 2.95 & 0.001 \\
\hline \multicolumn{4}{|c|}{ Consultation with a counsellor, psychologist or social worker } \\
\hline Yes & 1.00 & - & \\
\hline No & 0.72 & 0.60 to 0.87 & 0.001 \\
\hline Life orientation test & 1.07 & 1.06 to 1.09 & 0.001 \\
\hline
\end{tabular}

spiritual healing. Use of another alternative therapy sometimes or often was associated with a 2.47 (95\% CI 2.07 to 2.95 ) times greater likelihood of using prayer or spiritual healing compared to women who did not use an alternative therapy other than those aforementioned.

Women who did consult a counsellor, psychologist or social worker were 1.39 (95\% CI 1.15 to 1.67 ) times more likely to use prayer or spiritual healing than women who did not consult a counsellor, psychologist or social worker. For every one point increase on the life orientation test (ie, a more positive outlook on life) there is a corresponding $7 \%$ increase in the likelihood that women will use prayer or spiritual healing 1.07 (95\% CI 1.06 to 1.09 ).

\section{DISCUSSION}

This research has highlighted a number of important issues regarding prayer or spiritual healing and, in particular, its use for chronic illness, and is the first ever study examining the use of prayer or spiritual healing using a nationally representative sample of women. 
Current findings indicate that prayer or spiritual healing is regularly used by $26 \%$ of women aged 59 64 years. This is lower than findings from previous research conducted in the USA, where it was estimated that prayer for one's own health was used among $43 \%$ of adults, $24.4 \%$ received intercessory prayer for their own health and participation in a prayer group to assist health was utilised by $9.6 \%$ of the population. ${ }^{10}{ }^{20}$ Further, prayer for health was estimated to be used among $53 \%$ of women overall, and in $48-51 \%$ of adults aged between 50 and 69 years, which may reflect higher trends of prayer use among Americans residing in highly religious areas, such as the south-western states. ${ }^{20}$ Greater use of prayer or spiritual healing in the Australian setting compared to the UK, where spiritual healing was used in $0.7 \%$ of the population, likely due to the exclusion of prayer as a complementary therapy and the use of a smaller sample of CAM users $(n=200) .{ }^{27}$

Presence of symptoms of chronic illnesses was a significant predictor of use of prayer or spiritual healing, which is consistent with previous research on prayer use in the USA. $^{20}$ That women may be using prayer or spiritual healing as a means of managing health-related symptoms of chronic illnesses such as depression, anxiety, severe tiredness, cancer or other major illnesses, is an important finding, given that up to half of outpatient visits to mainstream healthcare providers are related to physiological symptoms for which there are no known physiological or biological correlates. ${ }^{28}$ In these instances potential global effects of prayer or spiritual healing, such as reductions in psychopathology and general distress, may enhance self-management among women managing chronic illnesses. ${ }^{29}$ This may be an important contribution in the context of comorbid diagnoses of depression and anxiety among women with chronic illnesses, given the high prevalence of somatic symptom burden and amplified chronic illness symptoms. ${ }^{28}$

Increased use of prayer or spiritual healing among women with severe tiredness is also relevant, given the increased distress due to lack of legitimisation of chronic fatigue syndrome from conventional healthcare providers among some patients and the increased association this has to comorbid diagnoses of anxiety or depression. ${ }^{30}$ In this instance, utilisation of complementary therapies such as prayer or spiritual healing may assist with coping and reduce reliance on conventional healthcare practitioners for symptom management. This is consistent with previous literature where use of personal prayer was significantly associated with enhanced health locus of control. ${ }^{31}$ Previous research has also indicated that religiosity and spirituality are predictors of enhanced social support, cooperation, cognitive function and reduced depressive symptoms. ${ }^{32}$ That use of prayer may facilitate enhanced cooperation is an important finding, given that belief about symptoms among patients with chronic fatigue syndrome may lead to avoidance behaviours and restriction of activity, which in turn results in physical deconditioning, increased symptom prevalence and disability. ${ }^{33}$

Personal prayer has also been shown to significantly reduce psychological distress and depression 1 year post heart surgery and was used as a means of coping with postoperative symptoms among older adults. ${ }^{34}$ Further, personal prayer had a suppressive effect on distress and depression, thereby affecting patients with both high and low levels of health-related distress. ${ }^{34}$ This benefit is clinically relevant for women managing depression in the community and may assist healthcare providers to understand why women are more likely to be using prayer or spiritual healing as adjunct therapies. However, further research is required to understand the reasons for use among specific population groups with chronic illnesses.

Prayer or spiritual healing therapies may also affect psychological mediators that facilitate physiological benefits for women managing symptoms of chronic illnesses, including, but not limited to, cancer. ${ }^{35}$ For example, Sephton and Koopman ${ }^{36}$ found that women with metastatic breast cancer who highly valued spiritual expression had significantly increased immune function (increased white cell counts and lymphocytes). The identification of cancers other than breast or skin cancer as a significant predictor of the use of prayer or spiritual healing is consistent with the previous literature, where the cancer journey was significantly associated with increased spirituality. ${ }^{37}$ Intercessory prayer has been shown to improve spirituality among patients with various cancers. ${ }^{38}$ This result is of relevance given that 'spiritual pain' has been associated with adverse physical or emotional symptoms and decreased spiritual quality of life among patients with advanced cancer. ${ }^{39}$

Management of the terminal phase of chronic illnesses such as cancer requires an understanding of the likelihood of these patients facing an 'existential crisis', by which prayer or spiritual healing modalities may assist with coping, and how one defines themselves, creates meaning and finds peace. ${ }^{40-42}$ Koenig $^{43}$ found that use of spiritual coping was associated with situations deemed uncontrollable, which is relevant given that prayer has been found to be an important need in up to $50 \%$ of religious terminally ill patients. ${ }^{40}$

Increased use of prayer or spiritual healing was significantly associated with non-smokers and non-drinkers. This may reflect users of prayer or spiritual healing as women who have positive health-seeking behaviours or lifestyle patterns. This is supported by current results indicating that women who use prayer or spiritual healing are also more likely to be users of other complementary therapies. Bell et $a t^{20}$ also found that people who pray for their health were significantly more likely to use any CAM. In addition, increased religiosity has been associated with use of preventative health practices (Benjamins and Brown, 2004; Fox, Pitkin, Paul, Carson and Duan, 1998, in ref 20). 
Limitations include ambiguity regarding how prayer or spiritual healing was understood by the participants, duration or types of prayer (intercessory or personal) or spiritual healing, or conditions in which prayer or spiritual healing were used, as these were not provided in the ALSWH data. Use of prayer or spiritual healing was provided as a single option in the ALSWH questionnaire, thereby limiting separate analysis of the use of prayer compared to the use of spiritual healing. This is an area for future research. Further, bias may be introduced by means of the self-report method for data collection, however, limitations are minor compared to valuable information obtained by analysing a large nationally representative sample of women. ${ }^{23}$ The study was based on information on women, thus limits generalisability of findings to the population as a whole. A similar study on men would be an area for future research.

\section{CONCLUSION}

Prayer or spiritual healing is used widely within the community. Healthcare providers need to be mindful of use of prayer or spiritual healing as non-pharmacological adjunct therapies, particularly among women with poorer health status, managing chronic health symptoms and/or diagnosed chronic illnesses. Given that prayer or spiritual healing modalities are safe, low-risk strategies, it is in the interest of policymakers and healthcare providers to consider the prayer or spiritual healing practices of women managing chronic illnesses, and to provide a conducive environment for spiritual self-expression within a contemporary healthcare framework. ${ }^{14} 20$ Recommendations for future research include assessment of the efficacy and impact of prayer or spiritual healing, and reasons for use.

\section{Twitter Follow Angela Rao at @AngelaRao0983}

Contributors AR, DS, JLP and LDH contributed and conceptualised this manuscript. Statistical analysis was completed by AR and DS. Results were interpreted by AR, DS, JLP and LDH. LDH and DS guided the manuscript, and all authors were responsible for revisions.

Funding This research received no specific grant from any funding agency in the public, commercial or not-for-profit sectors.

Competing interests None declared.

Ethics approval Human Research Ethics Committees University of Newcastle, University of Queensland.

Provenance and peer review Not commissioned; externally peer reviewed.

Data sharing statement No additional data are available.

Open Access This is an Open Access article distributed in accordance with the Creative Commons Attribution Non Commercial (CC BY-NC 4.0) license, which permits others to distribute, remix, adapt, build upon this work noncommercially, and license their derivative works on different terms, provided the original work is properly cited and the use is non-commercial. See: http:// creativecommons.org/licenses/by-nc/4.0/

\section{REFERENCES}

1. Leder D. Spooky actions at a distance: physics, psi, and distant healing. J Altern Complement Med 2005;11:923-30.
2. Walach $\mathrm{H}$, Boesch $\mathrm{H}$, Lewith $\mathrm{G}$, et al. Effectiveness of distant healing for patients with chronic fatigue syndrome: a randomised controlled partially blinded trial (EUHEALS). Psychother Psychosom 2008;77:158-66.

3. Brown LB, Wierzbicka A. The human side of prayer: the psychology of praying. Birmingham. Religious Education Press, 1994:1-125.

4. Abbot NC, Harkness EF, Stevinson C, et al. Spiritual healing as a therapy for chronic pain: a randomized, clinical trial. Pain 2001;91:79-89.

5. Reiki Australia. Reiki Australia. In touch 2014 (cited 18 October 2014). http://www.reikiaustralia.com.au/

6. Australian Foundation for Healing Touch Incorporated. Welcome 2014 (cited 18 October 2014). http://www.healingtouch.org.au/

7. Dossey L. Healing words: the power of prayer and the practice of medicine. New York: HarperCollins, 1993:1-291.

8. Benor DJ. Spiritual healing: scientific validation of a healing revolution. Wholistic Healing Pubns, 2001:1-597.

9. Cheung C, Wyman J, Halcon L. Use of complementary and alternative therapies in community-dwelling older adults. J Altern Complement Med 2007;13:997-1006.

10. Barnes PM, Powell-Griner E, McFann K, et al. Complementary and alternative medicine use among adults: United States, 2002. Semin Integr Med 2004;2:54-71.

11. Eisenberg DM, Davis RB, Ettner SL, et al. Trends in alternative medicine use in the United States, 1990-1997: results of a follow-up national survey. JAMA 1998;280:1569-75

12. Adams J, Sibbritt D, Broom A, et al. A comparison of complementary and alternative medicine users and use across geographical areas: a national survey of 1,427 women. BMC Complement Altern Med 2011;11:85.

13. Roberts L, Ahmed I, Hall S, et al. Intercessory prayer for the alleviation of ill health. Cochrane Database Syst Rev 2009;(2):CD000368.

14. Hodge DR. A systematic review of the empirical literature on intercessory prayer. Res Soc Work Pract 2007;17:174-87.

15. Hodge DR. Using prayer and other forms of positive mental energy in direct practice: an evidence-based perspective. Smith Coll Stud Soc Work 2010;80:121-38.

16. Abbot NC. Healing as a therapy for human disease: a systematic review. J Altern Complement Med 2000;6:159-69.

17. Astin JA, Harkness E, Ernst E. The efficacy of "distant healing": a systematic review of randomized trials. Ann Intern Med 2000;132:903-10.

18. Crawford C, Sparber A, Jonas W. A systematic review of the quality of research on hands-on and distance healing: clinical and laboratory studies. Altern Ther Health Med 2003;9:96-104.

19. Conboy L, Patel S, Kaptchuk T, et al. Sociodemographic determinants of the utilization of specific types of complementary and alternative medicine: an analysis based on a nationally representative survey sample. J Altern Complement Med 2005;11:977-94.

20. Bell R, Suerken C, Quandt S, et al. Prayer for health among U.S adults: the 2002 National Health Interview Survey. Complement Health Pract Rev 2005;10:175-88.

21. Xue CC, Zhang AL, Lin V, et al. Complementary and alternative medicine use in Australia: a national population-based survey. $J$ Altern Complement Med 2007;13:643-50.

22. Brown WJ, Bryson L, Byles JE, et al. Women's health Australia: recruitment for a National Longitudinal Cohort Study. Women Health 1999;28:23-40.

23. Sibbritt D, Adams J, van der Riet $P$. The prevalence and characteristics of young and mid-age women who use yoga and meditation: results of a nationally representative survey of 19,209 Australian women. Complement Altern Med 2011;19:71-7.

24. Hosmer DW Jr, Lemeshow S. Applied logistic regression. John Wiley \& Sons, 2004.

25. Brown W, Bryson L, Byles J, et al. Women's health Australia: establishment of the Australian longitudinal study on women's health. J Womens Health Gend Based Med 1996;5:467-72.

26. Women's Health Australia. Sample 2014b (cited 16 June 2014). http://www.alswh.org.au/about/sample

27. Thomas K, Coleman P. Use of complementary or alternative medicine in a general population in Great Britain. Results from the National Omnibus survey. J Public Health (Oxf) 2004;26:152-7.

28. Katon W, Lin EH, Kroenke K. The association of depression and anxiety with medical symptom burden in patients with chronic medical illness. Gen Hosp Psychiatry 2007;29:147-55.

29. Greyson B. Distance healing of patients with major depression. J Sci Exploration 1996;10:447-65.

30. Lehman AM, Lehman DR, Hemphill KJ, et al. Illness experience, depression, and anxiety in chronic fatigue syndrome. J Psychosom Res 2002;52:461-5. 
31. McClain CS, Rosenfeld B, Breitbart W. Effect of spiritual well-being on end-of-life despair in terminally-ill cancer patients. Lancet 2003;361:1603-7.

32. Koenig HG, George LK, Titus P. Religion, spirituality, and health in medically ill hospitalized older patients. J Am Geriatr Soc 2004;52:554-62.

33. Taillefer SS, Kirmayer LJ, Robbins JM, et al. Psychological correlates of functional status in chronic fatigue syndrome. J Psychosom Res 2002;53:1097-106.

34. Ai AL, Dunkle RE, Peterson C, et al. The role of private prayer in psychological recovery among midlife and aged patients following cardiac surgery. Gerontologist 1998;38:591-601.

35. Connerley RC. Distant intercessory prayer as an adjunct to psychotherapy with depressed outpatients: a small-scale investigation. Union Institute \& University, 2003.

36. Sephton SE, Koopman C, Schaal M, et al. Spiritual expression and immune status in women with metastatic breast cancer: an exploratory study. Breast $J$ 2001;7:345-53.
37. Risberg T, Wist E, Kaasa S, et al. Spiritual healing among Norwegian hospitalised cancer patients and patients' religious needs and preferences of pastoral services. Eur J Cancer 1996;32:274-81.

38. Olver I, Dutney A. A randomized, blinded study of the impact of intercessory prayer on spiritual well-being in patients with cancer. Altern Ther Health Med 2012;18:18-27.

39. Delgado-Guay MO, Hui D, Parsons HA, et al. Spirituality, religiosity, and spiritual pain in advanced cancer patients. J Pain Symptom Manage 2011;41:986-94.

40. Hampton D, Hollis D, Lloyd D, et al. Spiritual needs of persons with advanced cancer. Am J Hosp Palliat Care 2007;24:42-8.

41. Frankl VE. Man's search for meaning. trans. Ilse Lasch. London: Hodder and Stoughton, 1964

42. Conti JM. The effects of intercessory prayer and transpersonal positive visualization on a hemodialysis population. Amherst: University of Massachusetts, 1999.

43. Koenig HG. Religious attitudes and practices of hospitalized medically ill older adults. Int J Geriatr Psychiatry 1998;13:213-24. 